\title{
A Corpus-based 3M Approach to the Teaching of English Unaccusative Verbs
}

\author{
Junhua Mo \\ School of Foreign Languages, Soochow University, China
}

\begin{abstract}
This study attempts to take a corpus-based approach to teaching English unaccusative verbs to Chinese students in a $3 \mathrm{M}$ way, which is a combination of implicit and explicit instructions. It finds that Chinese students welcome the corpus-based approach and are excited to see the concordance lines retrieved from the Chinese English Learner Corpus (CLEC). And they prefer explicit instructions by the teacher, which they think is insightful and useful. But they are not keen about figuring out the usages of the target words from the context, which they think is a bit boring. This suggests that Chinese students, who have been accustomed to being spoon-fed by their teachers, are not highly autonomous. This study concludes that the corpus-based 3M approach is in general effective for the teaching of English unaccusative verbs.
\end{abstract}

Index Terms - vocabulary teaching, English unaccusative verbs, Corpus-based approach, 3M approach

\section{INTRODUCTION}

The Unaccusative Hypothesis (Burzio, 1986; Perlmutter, 1978) suggests that intransitive verbs are not homogenous, but can be further divided into unaccusatives (e.g., appear, happen, melt, and sink) and unergatives (e.g., cry, jump, jump, and work). The sole NP of an unaccusative plays the role of theme and is projected as the object at the D-structure, whereas the only NP of an unergative acts as the agent and is projected as the subject the D-structure. As far as English is concerned, both unaccusatives and unergatives canonically appear the NP-V structure, which makes it hard to detect their difference on the surface. What's more, many English unaccusatives can be used as transitives without any morphological changes. Therefore, English unaccusatives are divided into non-alternating and alternating unaccusatives, according to their ability to participate in the transitivity alternation. Alternating unaccusatives can be used as both intransitives and transitives (e.g., The ice melted and The sun melted the ice); whereas non-alternating ones can be used only as intransitives, but not as transitives (e.g., The ball disappeared and ${ }^{*}$ The magician disappeared the ball).

\section{LITERATURE REVIEW}

\section{A. L2 acquisition of English Unaccusative Verbs}

English, as a configurational language, represents grammatical relations in a sentence configurationally rather than in terms of morphological case (Zobl, 1989). Since English is a nominative-accusative language system, its canonical alignment between thematic roles and grammatical relations is agent-subject and theme-object. That is to say, the thematic role of agent is typically projected to the grammatical subject position, while the thematic role of theme is typically projected to the grammatical object position. Zobl (1989) suggests that this non-canonical way of mapping without any morphological changes poses a challenge to L2 learners in acquiring English unaccusatives.

It is found that L2 learners are apt to make errors with English unaccusatives, irrespective of their first languages (L1) (Cai, 2000; Deguchi and Oshita, 2004; Hirakawa, 2000; Hwang, 1999; Ju, 2000; Mo 2012; Yip, 1995; Zobl, 1989). Montrul (2005) notes that there are four types of unaccusative errors in L2 English. First is passivization, which refers to L2 learners' production and acceptance in judgment tasks of non-alternating and alternating unaccusatives in the NP-Be-Ven structure (e.g., "The book was disappeared or "The bridge was broken). Second is avoidance, which refers to L2 learners' reluctance to accept non-alternating and alternating unaccusatives in the NP-V structure in judgment tasks (e.g., A leaf fell or The fish burned in the pan). The third error is L2 learners' production and acceptance in judgment tasks of non-alternating unaccusatives in the V-NP structure with or without an expletive (e.g., There/It/ arrived a strange man). The fourth error is transitivization, which refers to L2 learners' production and acceptance in judgment tasks of non-alternating unaccusatives in the NP1-V-NP2 structure (e.g., "The man disappeared his wallet). Of these four types of unaccusative-related errors, passivization is most frequently reported. According to Oshita (2000), it is one of the most universal, conspicuous and persistent errors of L2 English. In contrast, avoidance is much less noticeable. It won't become an issue unless in experimental settings like judgment tasks. Production of postverbal NP structures for unaccusatives is often limited to L2 learners whose L1s have null expletives. Transitivization is observable in L2 English, but much less frequently than passivization.

Sorace (1995) observes that there are variations among unaccusatives in that some verbs show consistent unaccusative behaviors across different languages and in different contexts while other verbs do not. In her study of

${ }^{1}$ The * symbol is a mark of errors. 
Italian unaccusatives, Sorace identifies three pairs of semantic determinants: dynamic/static, telic/atelic, and concrete/abstract. According to these criteria, non-alternating unaccusatives are judged to be the core unaccusatives, whereas alternating unaccusatives are considered to be the most peripheral unaccusatives. Sorace suggests that the acquisition of unaccusatives is affected by their positions on the unaccusative hierarchy. Verbs higher on the hierarchy are acquired earlier than those at lower positions. Since non-alternating unaccusatives are placed higher on the hierarchy than alternating unaccusatives, they are predicted to be acquired before the latter.

Oshita (2001) proposed the Unaccusative Trap Hypothesis, which is a three-stage model, to account for the L2 acquisition of unaccusatives. At Stage 1, L2 learners make no distinction between unaccusatives and unergatives, due to the canonical Subject-Verb sentence pattern in the input. They fail to perceive the difference that the subject of the unaccusative verb has no volition and therefore is not the agent, although that of the unergative verb is. At this stage, unaccusatives are lexically misanalyzed as unergatives and consequently misrepresentated as unergatives at the syntactic levels. At Stage 2, some learners discover the subtle difference between seemingly identical intransitive verbs and restructure their interlanguage grammars accordingly. Now they realize that the subjects are not always the agents. Some are actually the objects. This correct lexical analysis leads them to arrive at the correct deep structure representation, where the internal argument is placed in the object position. However, when they attempt to move the internal argument of the unaccusative verb from the D-structure object to the S-structure subject, they tend to overtly mark this NP movement with the salient passive morphosyntax be + Ven. That is to say, the deep structure representation is correct, but the surface structure representation is wrong. At Stage 3, these learners make further progress and are capable of both correct lexical analysis and correct syntactic representations. Not only are they aware that the only NP of the unaccusative verb is its internal argument, which should be projected on the object position on the deep structure representation, but also refrain themselves from overtly marking the NP movement with the salient passive morphosyntax be + Ven. In a word, they become targetlike in the use of unaccusatives.

\section{B. Corpus-based Language Learning}

Corpus is a body of written text or transcribed speech which can serve as a basis for analysis and description (Kennedy, 1998). Corpora can be classified in different ways and used for different purposes. For example, they can be divided into general corpora and specialized corpora by compiling purposes and spoken and written corpora according to language channels. They can be divided into diachronic and synchronic with reference to the time and native corpora and learner corpora according to the contributor of the text source. The past few decades have witnessed a fast development of corpus linguistics. For a long time, however, corpora have been used as a new tool for language research. The potentials of corpora in language teaching are not recognized until the recent two or three decades. Now more and more learner corpora and textbook corpora are being built and put into use.

Johns (1991) initiated the idea of Data Driven Learning (DDL), which advocates the use of computer-generated concordances to engage students in exploring regularities of patterning in the target language and the development of activities and exercises based on concordances output. DDL can be conducted in a variety of ways: (1) searching for example sentences, (2) filling the gaps, (3) putting in order, (4) finding a rule, and (5) having a quiz. In these activities, learners have to work and look for answers themselves, which will convert them from passive learners into active ones. Their learning motivation will be enhanced in the discovery process and their comprehension and retention of the target words and rules will be enhanced, too.

\section{Implicit and Explicit Vocabulary Teaching}

As the building blocks of the English language, vocabulary has always occupied an important place in the process of English teaching and learning. Over the years, a vast array of vocabulary instruction methods have been proposed. Numerous as they are, they can be divided, according to the directness of the teaching method, into explicit teaching, implicit teaching and a combination of the two. Explicit teaching suggests that direct attention should be given to vocabulary, which should be taught in a decontextualized way before they are explained from various aspects (Sokman, 2002). In contrast, implicit teaching argues that vocabulary should be taught to students via some activities in an unconscious way (Nagy, 2002). Ellis (1994) notes that explicit instruction impart vocabulary knowledge to the learners directly and ask them to do some exercises accordingly, while implicit teaching asks the learners to induce rules from the given examples by themselves. It has been found that both approaches have strengths and weaknesses. Sokmen (2002) admits that teaching vocabulary without reference to their contexts will relieve the cognitive load imposed on the learners on the one hand, but will make the learning process boring and uninvolving. Coady (2001) point out that implicit vocabulary instruction may be effective, but is time-consuming. And it is particularly difficult for less proficient learners as they are asked to guess the meaning of an unknown word from a context full of unknown words. As a result, they are likely to make mistakes. In light of these problems, more and more researchers are calling for a combination of the two methods in the actual vocabulary teaching. They suggest that the two methods are not only complementary, but also dependent on each other (Nation, 2003; Schimitt, 2008). That is to say, the implicit learning of guessing meaning from the context for learners of higher proficiencies will be greatly boosted by explicit instructions. Therefore, Sokmen (2002) notes that the pendulum has swayed from the direct vocabulary teaching to the indirect teaching and now back to the middle: implicit and explicit learning. 


\section{TEACHING EXPERIMENT}

\section{A. Rationale}

The 3M approach designed for unaccusative accusatives is a combination of implicit and explicit vocabulary teaching. It consists of 3 stages. Stage 1 is to make the students meet the English unaccusatives and learn them implicitly. Stage 2 is to make them muddle through these verbs with explicit instructions from the teachers. Stage 3 is to enable them to master these verbs after going through the first two stages. The procedure and specifics of this teaching approach is shown in Figure 1.
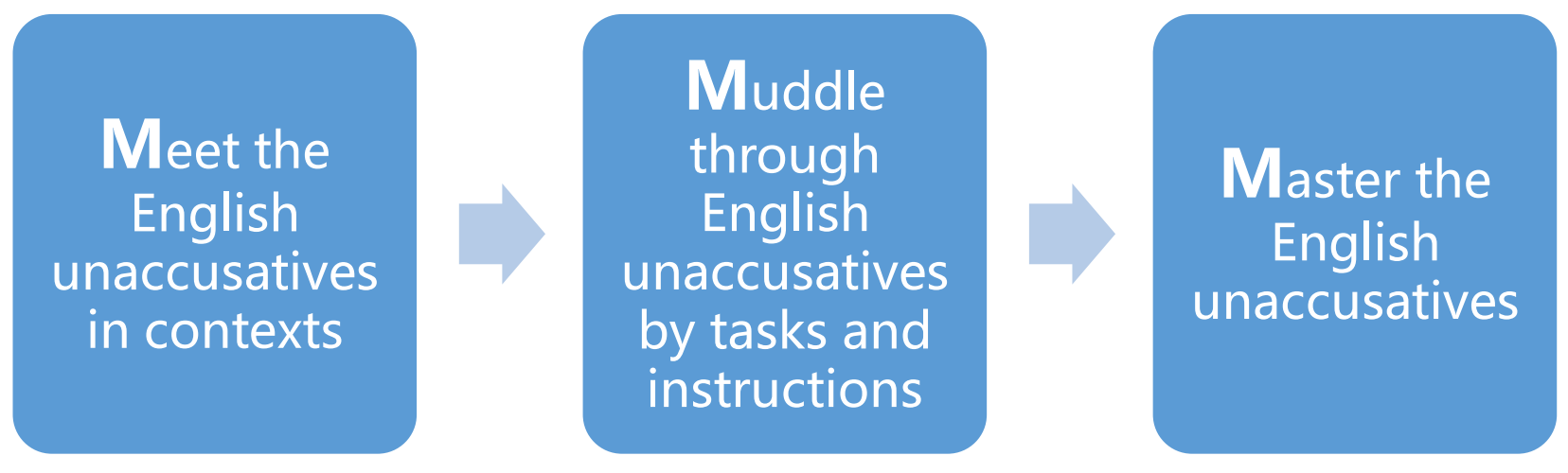

Figure 1. The $3 \mathrm{~m}$ Approach to the Teaching of English Unaccusatives

\section{B. Research Questions}

This study had three research questions to answer. (1) What do Chinese students think of the corpus-based approach? (2) What do Chinese students think of the 3M approach, which is composed of implicit and explicit teaching? (3) Is the corpus-based 3M approach effective for the teaching of English unaccusatives?

\section{Subjects}

The students of this study are a group of 26 college students, who are second and third-year English majors from an independent college of a university in Jiangsu Province, China. They participated in this experiment when they were taking a selective course instructed by the author.

\section{Materials}

The vocabulary teaching materials used in this study are collected on the Internet by the author himself. Some of them are adapted by the author for the sake of teaching purposes and conveniences. These materials include reading passages and vocabulary exercises containing the target words.

The corpus used in this study is Chinese Learner English Corpus (CLEC), which is constructed by Gui and Yang (2002). It is a one-million-word corpus with five sub-corpora: ST2, ST3, ST4, ST5 and ST6. In terms of genre, CLEC is a written corpus composed of test compositions and free writings produced by Chinese learners at different levels. ST2 is contributed by senior high school students, while the others are all supplied by college students. The target words investigated in this study are common, high-frequency English unaccusatives, non-alternating and alternating alike. Some of the non-alternating unaccusatives are appear, arrive, die, disappear, happen, rise and remain, and some of the alternating unaccusatives are begin and increase.

\section{E. Methods}

The teaching methods used in this study include classroom readings, corpus searching, quizzes, presentations and discussions. Follow-up interviews with students are conducted to evaluate the effect of the teaching.

\section{F. Procedures}

The procedures of this study can be seen in Figure 1. The second stage of the chart is the focus of the experiment and therefore is given the uttermost attention. 


\section{A. Implicit Teaching of Non-alternating Unaccusatives}

Contexts containing non-alternating unaccusatives were provided to the students. A sample of the contexts is shown in Table 1.

TABLE 1:

CONTEXTS CONTAINING NON-ATLERNATING UNACCUSATIVES

\begin{tabular}{|c|l|l|}
\hline $\begin{array}{c}\text { Non-alternating } \\
\text { unaccusatives }\end{array}$ & \multicolumn{1}{|c|}{$\begin{array}{c}\text { Absence of a conceptualizable agent in } \\
\text { discourse }\end{array}$} & \multicolumn{1}{c|}{$\begin{array}{c}\text { Presence of a conceptualizable agent in } \\
\text { discourse }\end{array}$} \\
\hline Fall & $\begin{array}{l}\text { It became very cold. Leaves fell to the ground } \\
\text { quickly. }\end{array}$ & $\begin{array}{l}\text { Strong wind blew for hours. Leaves fell to the } \\
\text { ground quickly. }\end{array}$ \\
\hline Appear & The fog cleared. The house appeared slowly. & $\begin{array}{l}\text { The little boy tried to pull his toy house out of } \\
\text { the sand. The house appeared slowly. }\end{array}$ \\
\hline Exist & $\begin{array}{l}\text { The old church was built with stones. It has } \\
\text { safely existed for many years. }\end{array}$ & $\begin{array}{l}\text { The local people took very good care of the old } \\
\text { church. It has safely existed for many years. }\end{array}$ \\
\hline Remain & $\begin{array}{l}\text { John failed to do a better job this year. His } \\
\text { salary remains at the same level as last year. }\end{array}$ & $\begin{array}{l}\text { John's boss refused to increase his salary this } \\
\text { year. His salary remains at the same level as last } \\
\text { year. }\end{array}$ \\
\hline
\end{tabular}

When asked how they felt about being asked to read the target words shown in Table 1, many students said that they were not very interested. "I can't see the point. I know these words. I'm not interested." Student A complained. Her feeling is shared by other students. For example, Student B said that "It's almost a waste of time in class. I feel at a loss. I can't figure out the purpose of doing so." This suggests that Chinese students are not used to implicit teaching. They are not capable of gleaning the semantic and syntactic properties of the non-alternating unaccusatives from the context.

\section{B. Explicit Teaching of Non-alternating Unaccusatives}

When asked if they had already known the target words, many of the students said yes. So the author started to analyze the unique syntactic properties of the non-alternating unaccusatives by referring to the L1 Chinese.

Non-alternating unaccusatives exist in both English and Chinese. And they share some similarities. First, both of them are morphologically unmarked, when compared with unergatives. Unlike French and Italian, which select different auxiliaries for the perfective use of unaccusatives and that of unergatives, neither English nor Chinese marks their unaccusative/unergative distinction with any overt morphologies. Second, non-alternating unaccusatives in neither English nor Chinese can be used in the passive voice. For example, it is grammatically incorrect to produce English sentences like *What was happened yesterday and ${ }^{*}$ The leaves were fallen down. It is also wrong to utter Chinese sentences like*什么被发生了(Shenme Bei Fasheng Le) (What PASS happen PFV) or *树叶被掉了下来 (Shuye Bei Diao Le Xialai) (Leaf PASS fall PFV down come). The instructor reminded the students that the passivization error of English non-alternating unaccusatives had nothing to do with the influence of L1 Chinese.

English and Chinese unaccusatives are different from each other in some aspects. For example, it is easier to identify unaccusatives in Chinese than in English, because Chinese is featured by surface unaccusatity, which refers to the linguistic fact that the indefinite NP of a Chinese unaccusative can either be put preverbally (e.g., 三个人来了) (Sange

Ren Lai Le) (Three people come PFV) or postverbally (e.g., 来了三个人) (Lai Le Sange Ren) (Come PFV three people). When it comes to English, however, the postverbal use of NP for unaccusatives is much less common, as it can only be found in the there-insertion construction (e.g., There arrived a policeman)and the locative-inversion construction (e.g., From the distance came a young man).

When asked what English verbs can be used in the there-insertion construction, the students answered sporadically and uncertainly. Some suggested verbs like come, appear, and happen, and some suggested verbs like lie and exist. Under such circumstances, the teacher pointed out that non-alternating English unaccusatives, which denote a change of location (e.g., arrive, come, go, fall, and rise) or express existence and appearance (e.g., appear, happen, die, exist, and remain) can be used in the There-V-NP structure, as long as the postverbal NP is indefinite. Hearing this, the students came to realize that the surface subject of a non-alternating unaccusative is in fact its object at the underlying level. They said that they were greatly enlightened.

Then the instructor went on to say that Chinese students, like other L2 learners of English, tend to make errors with non-alternating English unaccusatives. As Montrul (2005) points out, the four errors are passivization, avoidance, postverbal NPs, and transitivization. Since avoidance only surfaces in judgment tasks, the instructor asked the students to find out the non-target uses of some non-alternating unaccusatives in CLEC. For example, the instructor asked them to search for the wrong uses of appear, die and happen in CLEC. When they came up with the needed concordance lines, they were very excited and deeply convinced. Some of the concordance lines the students yielded are listed in Table 2. 
TABLE 2:

SOME SAMPLES OF NON-ALTERNATING ENGLISH UNACCUSATIVE ERRORS IN CLEC

\begin{tabular}{|c|l|}
\hline Errors & Concordance lines \\
\hline \multirow{2}{*}{ Passivization } & A very unhappy thing was happened [vp7, 5-3]. \\
\cline { 2 - 2 } & And last year he was died [vp7, 2-2] from car, \\
\hline \multirow{2}{*}{ Postverbal NP } & Before it appeared the lunar eclipse \\
\cline { 2 - 2 } & These [wd3, 1-] appeared some trials of mercy killing recently in China, too. \\
\hline \multirow{2}{*}{ Transitivization } & Her former beautiful fact [wd3, S-] shrank by degrees, and appeared [wdl, 1-2] many wrinkles. \\
\cline { 2 - 2 } & But these have rised [fm2, - ] [wd3, S-] the satues [fml, -] of women indeed? \\
\hline
\end{tabular}

Concordance lines like the above impressed the students, convincing them that they were prone to error with English non-alternating unaccusatives. The author took the opportunity to elaborate on the usages of these verbs that they cannot be used in the passive voice, in the there-insertion construction without there or as a transitive verb.

Yip (1995) suggests that to acquire the non-alternating unaccusatives, L2 learners should work to expunge the ungrammatical passive use of these verbs from their interlanguage grammar. Her viewpoint was not supported by the concordance lines in Table 1. Therefore, the instructor argued that the acquisition task of non-alternating unaccusatives is more complex than what Yip suggested. To help students fully acquire these verbs, L2 instructors should explicitly explain the semantic and syntactic properties of these seemingly easy intransitive verbs so that they can store such linguistic knowledge in their mind and refrain them from making errors. What's more, the instructors might as well introduce the unaccusative-related theories to the students. For one thing, he or she can tell students that unaccusatives, predicted by the Unaccusative Trap Hypothesis, are more vulnerable to errors than unergatives. For another, the instructor can tell the students that some non-alternating unaccusatives are peripheral and more susceptible to errors than others, as suggested the Unaccusative Hierarchy Hypothesis (Sorace, 1995). Therefore, they should be more alert when dealing with peripheral non-alternating unaccusatives. To test the learners' mastery of the explicit instructions, the instructor can ask the students to fill in the blanks with the appropriate form of the word given in the ensuing brackets in contexts indicating a conceptualizable agent (e.g., As the heavy flood destroyed the post office network, my letter (arrive) several days later).

\section{Implicit Teaching of Alternating Unaccusatives}

Yip (1995) suggests that L2 learners should realize the functional difference between the intransitive use and passive use of English alternating unaccusatives. Therefore, the instructor provided a list of sentences with the alternating unaccusatives used in both forms, asking the students to think about the differences by themselves. A sample list is shown in Table 3.

TABLE 3:

INTRANSITIVE AND PASSIVE USES OF ALTERNATING UNACCUSATIVES

\begin{tabular}{|c|l|l|}
\hline $\begin{array}{c}\text { Alternating } \\
\text { unaccusatives }\end{array}$ & \multicolumn{1}{|c|}{ Intransitive uses } & \multicolumn{1}{|c|}{ Passive uses } \\
\hline Change & $\begin{array}{l}\text { The soup was not kept in the refrigerator. Its } \\
\text { taste changed slowly. }\end{array}$ & $\begin{array}{l}\text { The soup was not kept in the refrigerator. Its } \\
\text { taste was changed slowly. }\end{array}$ \\
\hline Decrease & $\begin{array}{l}\text { It didn't rain for a long time. The water level of } \\
\text { the pond decreased gradually. }\end{array}$ & $\begin{array}{l}\text { It didn't rain for a long time. The water level of } \\
\text { the pond was decreased gradually. }\end{array}$ \\
\hline Melt & $\begin{array}{l}\text { The weather became mild. The snow melted } \\
\text { quickly. }\end{array}$ & $\begin{array}{l}\text { The weather became mild. The snow was } \\
\text { melted quickly. }\end{array}$ \\
\hline Sink & The small boat leaked. It sank slowly. & The small boat leaked. It was sunk slowly. \\
\hline
\end{tabular}

The students told the instructor that they were not very clear about the meaning of the sample sentences, although they had a vague idea that the sentences were focused on the choice of whether to use the target verbs in the passive voice or not. They asked the teacher to be explicit.

\section{Explicit Teaching of Alternating Unaccusatives}

The instructor first of all pointed out that L2 learners tended to passivize English alternating unaccustives (e.g., ${ }^{*}$ For last 15 years computers have drastically affected our life and this will be continued in the future). Their tendency to do so can be attributed to their heavy reliance on an external force to trigger the occurrence of an event. Then the instructor asked the students to search for the passive uses of begin and increase in CLEC. When they came up with the needed concordance lines, they were surprised to find that Chinese students tended to passivize alternating unaccusatives in a context that didn't suggest a need to do so. Some of the concordance lines the students yielded are listed in Table 4.

TABLE 4:

SOME SAMPLES OF ALTERNATING ENGLISH UNACCUSATIVE ERRORS IN CLEC

\begin{tabular}{|c|l|}
\hline Errors & \\
\hline \multirow{4}{*}{ Passivization } & The meeting was begun [vp7, 3-0] \\
\cline { 2 - 3 } & Another new year is [vp7, 1-1] begun. \\
\cline { 2 - 3 } & Now the speed of all the trains in China has been increased. \\
\cline { 2 - 3 } & Salaries are increased and living condition improved. \\
\hline
\end{tabular}


The instructor pointed out that it is unnecessary or inappropriate to passivize all alternating unccusatives in all contexts. Sometimes the unaccusative use itself is simple and adequate (e.g., Being very old, the wooden bridge broke gradually). However, L2 learners are reluctant to do so with alternating unaccusatives denoting a strong external causation (e.g., break, drop, change, and improve). It has been widely found that L2 learners are unwilling to accept and produce a sentence like The window broke (Mo, 2016). The concordance lines in Table 4 serve as further evidence for this unwillingness. It seemed that Chinese students had difficulty in using alternating unaccusatives as unaccusatives.

Mo (2016) finds that English alternating unaccusatives are not acquired equal in that L2 learners only master the transitive and passive uses of verbs denoting a strong external causation (e.g., break and drop) and the intransitive use of verbs with a weak external causation (e.g., sink and melt). Based on this finding, the instructor told the students to choose and decide the appropriate form of the alternating unaccusatives according to the given contexts. There is no need for them to overcorrect themselves and avoid the passive use of alternating unaccusatives at all.

\section{E. Effect of the Corpus-based 3M Approach to the Teaching of English Unaccusatives}

In the follow-up interviews, the students told the instructor that the corpus-based approach aided with implicit and explicit instructions was an interesting, involving and instructive method. Compared with the traditional classroom vocabulary teaching method, it had several advantages. First, it had a technical attraction in that it taught students to search in corpora. Second, the combination of implicit and explicit instructions enhanced the students' understanding of the target verbs. Third, the explicit instructions provided by the teacher were not only in-depth but also theoretical, which deepened their understanding of the English language. When it comes to disadvantages, some students complained that implicit teaching featured by contexts was not very interesting. They preferred the explicit teaching by the teacher, which suggested that these Chinese students were lazy and lacking in motivation and autonomy. They must have got used to the traditional cramming method.

\section{CONCLUSION}

This study reported a teaching experiment on how to teach English unaccusative verbs to Chinese students. By taking a learner corpus-based approach and a $3 \mathrm{M}$ method, which is a combination of implicit and explicit instructions, this study made three findings. First, Chinese students are delighted to have access to the corpus, which greatly aroused their interest in the classroom learning. Second, Chinese students are more accustomed to being taught explicitly by the instructor than to figuring out the usages of the target words from the sample sentences by themselves. Third, the corpus-based, $3 \mathrm{M}$ approach is a good way to teach Chinese students the English unaccusatives. This study suggested that more efforts should be made in the future to explore how to conduct the teaching of English unaccusatives to L2 learners.

\section{ACKNOWLEDGEMENTS}

This paper is a result of three research projects. The first one is Variations in EFL learners' acquisition of English unaccusative verbs: Implications for computer-aided language teaching practices (14YJC740068) funded by the Ministry of Education, China. The second one is A multi-factorial approach to L2 acquisition of English causative alternation (2017SJB1312) funded by the Department of Education, Jiangsu Province. The third one is Building up an excellent comprehensive English course (3510300818) funded by Wenzheng College, Soochow University.

\section{REFERENCES}

[1] Burzio, L. (1986). Italian syntax: A government-binding approach. Dordrecht: Reidel.

[2] Cai, Y. (2000). Prominence of causativization and its influence on L2 acquisition. Modern Foreign Languages 23, 174-182.

[3] Coady, J. (2001). L2 vocabulary acquisition through extensive reading. In Coady, J. \& T. Huckin (eds.). Second Language Vocabulary Acquisition. Shanghai: Shanghai Foreign Language Education Press, 225-237.

[4] Deguchi, A. \& H. Oshita. (2004). Meaning, proficiency and error types: Variations in nonnative acquisition of unaccusative verbs. In Foster-Cohen. S. H., M. S. Smith, A. Sorace \& M. Ota (eds.), EuroSLA yearbook. Amsterdam: John Benjamins, 41-65.

[5] Ellis, N. C. (1994). Vocabulary Acquisition: The implicit ins and outs of explicit cognitive mediation. In Ellis, N (ed.). Implicit and Explicit of Languages. London: Academic Press, 211-282.

[6] Gui, S. C. \& H. Z. Yang. (2003) Chinese learner English Corpus. Shanghai: Shanghai Foreign Language Education Press.

[7] Hwang, J. B. (1999). Learnability and the L2 development of English unaccusative verbs. Journal of the Applied Linguistic Association of Korea 15, 65-87.

[8] Johns, T. (1991) From printout to handout: Grammar and vocabulary teaching in the context of data-driven learning. In Johns, T. \& King, P. (eds). Classroom Concordancing. Birmingham: ELR, 78-115.

[9] Ju, M. K. (2000). Overpassivization errors by second language learners: The effect of conceptualizable agents in discourse. Studies in Second Language Acquisition 22, 85-111.

[10] Kennedy, G. (1998). An Introduction to Corpus Linguistics. New York: Addison Wesley Longman Limited.

[11] Mo, J. H. (2012). An Investigation of Chinese Learners' Acquisition of the Distinction between English Unaccusative and Unergative Verbs. Journal of PLA University of Foreign Languages 4: 60-65.

[12] Mo, J. H. (2016). Between-verb variations in Chinese learners' acquisition of English alternating unaccusative verbs: A new 
test of the Semantic Structure Theory and the Entrenchment Hypothesis. Journal of Xi'an International Studies University 3: 65-71.

[13] Montrul, S. (2005). On knowledge and development of unaccusativity in Spanish L2 acquisition. Linguistics, 43, 1153-1190.

[14] Nation, I. S. P. (2003). Teaching and learning vocabulary. Beijing: Foreign Language Teaching and Research Press.

[15] Nagy, W. (2002). On the role of context in first- and second-language vocabulary learning. In Schmitt, N. \& M. Mc Carthy (eds.) Vocabulary: Description, acquisition and pedagogy. Shanghai: Shanghai Foreign Language Education Press, 64-83.

[16] Oshita, H. (2000). What is happened may not be what appears to be happening: a corpus study of "passive" unaccusatives in L2 English. Second Language Research, 16, 293-324.

[17] Oshita, H. (2001). The unaccusative trap in second language acquisition. Studies in Second Language Acquisition 23, $279-304$.

[18] Perlmutter, D. (1978). Impersonal passives and the unaccusative hypothesis. In Proceedings of the 4th Berkeley Linguistics Society. Berkeley: University of California, 157-189.

[19] Schmitt, N. (2008). Instructed second language vocabulary learning. Language Teaching Research 4: 329-363.

[20] Sokmen, A. J. (2002). Current trends in teaching second language vocabulary. In Schmitt, N., \& M. Mc Carthy (eds.). Vocabulary: Description, acquisition and pedagogy. Shanghai: Shanghai Foreign Language Education Press, 237-257.

[21] Sorace, A. (1995). Acquiring linking rules and argument structure in a second language. In Eubank. L., L. Selinker \& M. S. Smith (Eds.), The current state of interlanguage: Studies in honor of William E. Rutherford. Amsterdam: John Benjamins, 153-175.

[22] Yip, V. (1995). Interlanguage and learnability: From Chinese to English. Amsterdam: John Benjamins.

[23] Zobl, H. (1989). Canonical typological structure and ergativity in English L2 acquisition. In Gass, S. \& J. Schachter (eds.), Linguistic perspectives on second language acquisition. Cambridge, UK: Cambridge University Press, 203-221.

Junhua Mo was born in Changzhou, China, in 1977. He received his PhD in applied linguistics from Nanjing University in 2008. Since then, he has been teaching English in School of Foreign Languages, Soochow University. His major interests include second language acquisition, syntax and corpus linguistics. 